\title{
ANALISIS STRATEGI PEMASARAN PUPUK PADA PT. SUNAN DRAJAT LAMONGAN
}

\author{
Anisa Solikhawati \\ Helmina Ardyanfitri, S.M.,M.M
}

Fakultas Ekonomi dan Bisnis Islam, Program Studi Ekonomi Syariah

Universitas Islam Negeri Sunan Ampel Surabaya

\begin{abstract}
Abstrak
Pondok pesantren merupakan lembaga akademis dan spiritualis yang memiliki pengaruh besar dalam melahirkan kader-kader yang berkarakter dan berkompeten. Oleh karena itu, dengan seiring berkembangnya zaman pondok pesantren perlu meningkatkan eksistensinya di ranah domestik maupun internasional, selain berkontribusi mengkader generasi spiritual juga dengan ikut berkontribusi dalam menopang perekonomian negara dengan melahirkan santripreneur.

Tujuan dari penelitian ini adalah untuk mengetahui lebih dalam tentang strategi pemasaran yang dilakukan oleh PT. Sunan Drajat Lamongan (SDL). Pondok Pesantren Sunan Drajat Lamongan sebagai pondok pesantren pelopor telah memiliki banyak bidang entrepreneur yang dapat memberdayakan masyarkat di bidang ekonomi dengan didirikannya PT. Sunan Drajat Lamongan yakni pembuatan pupuk dolomit dan fosfat. Strategi pemasaran adalah proses perencanaan yang disusun secara sistematisdan menyeluruh yang digunakan sebagai panduan untuk melakukan kegiatan pemasaran agar mencapai tujuan perusahaan yakni memperoleh laba. Untuk mencapai tujuan tersebut, setiap perusahaan harus mengelola manajemen perusahaan untuk menuju ketatnya persaingan usaha. Perlu diperhatikan bahwa potensi perusahaan dapat dilihat dari faktor internal dan ekternalnya yaitu sumber dayanya baik aset dan juga manusia, alat produktifitas perusahaan, legalitas perusahaan dan lain sebagainya.dan sebagainya

Penelitian ini menggunakan metode pendekatan kualitatif menggunakan studi literatur dan akan dianalisis secara sistematis. Analisis strategi pemasaran menunjukkan adanya peningkatan potensi pupuk dolomite dan fosfat PT. Sunan Drajat Lamongan pada hasil Marketing Mix (bauran pemasaran) yakni 4P (Product, Price, Place dan Promotion) dan analisis SWOT. Hasil menunjukkan bahwa PT. Sunan Drajat Lamongan dalam kegiatan pemasarannya dengan memanfaatkan kekayaan sumber daya alam (SDA) didaerah sekitarnya dan mengelolanya dengan berbagai jenis produknya. Pada tempat (distribusi) PT. Sunan Drajat Lamongan cukup strategis karena terletak di daerah perbatasan. Penetapan harga ditentukan sesuai dengan harga pasaran dan juga telah disahkan produk telah ber-SNI yang terbukti akan kualitas sehingga mempengaruhi minat pembeli. Pendistribusiannya juga sudah dilakukan ke berbagai kota di Inonesia serta melakukan ekspansi ke luar negeri. Dalam mempromosikan produknya PT. Sunan Drajat Lamongan memakai internet marketing yaitu
\end{abstract}


social media dan website, menyebarkan email ke perusahaan maupun instansi, menjadi sponsor kegiatan, dan mouth to mouth.

\section{Kata Kunci : Strategi Pemasaran, Pupuk, Pondok Pesantren, SWOT, PT. Sunan Drajat Lamongan}

\section{PENDAHULUAN}

Entrepreneur pada era saat ini menjadi aspek yang dapat mengentaskan permasalahan tentang pengangguran. Dalam proses pembentukan karakter, program entrepreneur dapat mengembangkan karakter yang rajin, tanggung jawab, dan kualitas yang tinggi pada pribadi seseorang untuk dapat memenuhi kualifikasi kerja. Dari proses pembelajaran ini memberikan semangat penuh dan memberikan wadah untuk menciptakan kader intelek sekaligus manfaat.

Lembaga yang terfokus pada entrepreneurship salah satunya adalah pondok pesantren. Selain untuk mengkader generasi rahmatan lil 'alamin juga membuka diri dengan berinovasi dalam berwirausaha dengan memanfaatkan sumber daya manusia dengan tetap menjalankan tujuan utama dari pondok pesantren. Pondok pesantren yang menerapkan entrepreneurship diantaranya adalah Pondok Pesantren Mukmin Mandiri Sidoarjo, Pondok Pesantren Daarul Muttaqin Malang, Pondok Pesantren Sidogiri Pasuruan dan Pondok Pesantren Sunan Drajat Lamongan.

Pondok Pesantren Sunan Drajat Lamongan kini memiliki beberapa bisnis, yakni : PT. Sunan Drajat Lamongan (SDL), Persada Radio FM, Air Minum Sunan Drajat (AIDRAT), , Persada Rihlah, Sari Mengkudu Sunan, Garam Samudra, BMT Sunan Drajat, Kemiri Sunan, Kopontren, Toserba Sunan Drajat, Persada TV, Fotocopy dan Percetakan, Rental Transportasi, Sunan Drajat Press, Bisnis Konveksi dan Bordir, Mustika Sunan Drajat, Restauran yang terletak di Malaysia dan lain sebagainya.

Eksistensi pondok pesantren baik salaf maupun modern hingga saat ini masih saja berlanjut hingga revolusi zaman. Pondok pesantren sebagai lembaga pendidikan memiliki peran untuk selalu relevan dengan kebutuhan zaman, terutama dalam hal perekonomian. Sehingga pondok pesantren mempunyai visi untuk menumbuhkan generasi penerus bangsa dalam menghadapi era industri 4.0. ${ }^{1}$

Riset ini memfokuskan pada entrepreneurship yang telah dikembangkan oleh pondok pesantren, hanya saja terdapat beberapa pondok yang mengembangkan program entrepreneurship guna mendidik para santri. Karena banyak lulusan santri yang tidak mempunyai kemampuan didunia kerja selain menjadi penerap edukasi. Pesantren mempunyai peran penting dalam melahirkan generasi bangsa, dengan mengembangkan kewirausahaan maka pondok pesantren menjadi salah satu penyumbang perekonomian negara. Hal ini dikarenakan pondok pesantren ingin terus eksis dengan melakukan transformasi dari masa ke masa.

\footnotetext{
${ }^{1}$ Habiburrohman, "Edupreneurship di Pondok Pesantren (Pondok Pesantren Sunan Drajat: Pesantren Wirausaha)", (Tesis-UIN Sunan Kalijaga Yogyakarta, 2018), h. 84.
} 
Melihat dari peran besar dari pondok pesantren maka hal ini perlu dikembangkan lagi. Strategi yang baik akan membuat pondok pesantren bertahan dalam persaingan antar kompetitorm dengan mengatur manajemen secara baik dan teratur. Manajemen yang baik dilihat dari bagaimana marketing, produksi, dan sumber daya (baik itu manusia maupun aset), dan juga segi keuangan. Strategi pemasaran merupakan aspek penting untuk mencapai keunggulan dalam bersaing dalam menghadapi ketatnya persaingan yang dihadapi oleh pondok pesantren demi menunjukkan eksistensinya di kancah domestik maupun internasional.

Pondok pesantren Sunan Drajat merupakan salah satu pondok pesantren yang besar di Jawa Timur yang memiliki tujuan untuk melahirkan generasi spiritual berbasis entrepreneur yang dapat membangun pribadi yang mandiri tidak menggantungkan diri kepada yang lain. Hal ini bertujuan untuk mendidik para santri untuk persiapan terjun ke masyarakat. Sejalan dengan salah satu misi pondok yakni "Menjadikan pondok pesantren yang baik dan bisa menjadikan santrinya sebagai santri yang berkompetensi serta dijadikan contoh bagi pondok pesantren lainnya". 2

PT SDL (Sunan Drajat Lamongan) ini merupakan unit wirausaha Pondok Pesantren Sunan Drajat untuk menopang perekonomian pondok. Usaha ini yang menjadi pelopor industry pupuk yang menawarkan produk pupuk berkualitas, murah serta ramah lingkungan. K. H Abdul Ghofur yang merupakan pendiri Pondok Pesantren Sunan Drajat sekaligus menjadi penemu ide entrepreneur. Hal ini didasarkan pada filosofi tujuh sap tangga Sunan Drajat yang memotivasi beliau untuk membangun salah satu santripreneur ini. Dalam pesan tersebut Sunan Drajat ingin agar orang yang lemah, terdzolimi dan marginal perlu di tolong. Maka dari itu, dapat menciptakan lembaga yang lebih berkualitas, dan mengalami kemajuan di era revolusi industry 4.0 ini dengan meningkatkan kemandirian pesantren melalui program santripreneur/entrepreneurship. ${ }^{3}$

Awal mula berdirinya PT SDL karena desa Kemantren pada saat itu memiliki sejumlah sumber daya alam yang belum dimanfaatkan oleh masyarakat sekitar. Akibatnya salah satu pengusaha yang memiliki pabrik dolomite menawarkan kepada Pondok Pesantren untuk dikelola dan menghasilkan pupuk dolomite di tahun 1981 seluas $4000 \mathrm{~m}^{2}$.

Proses pengembangan pun dimulai ditahun 1984 yang mengalihkan letak pabrik ke desa Banjarwati kurang lebih seluas 2 hektar. Pemilihan lokasi ini diperkirakan berhasil karena proses produksi mengalami perkembangan variasi pupuk yang semula hanya produksi pupuk dolomite kini bertambah menjadi pupuk pospat alam dibidang pertanian.

Hingga pada tahun 1995 pabrik ini beralih nama menjadi PT Indo Daya Sunan Drajat karena pertambahan bisnis usaha yakni di bidang jasa kontraktor. Pertumbuhan dan perkembangan semakin meningkat pada fase ini membuat pabrik ini melakukan varian produk

\footnotetext{
${ }^{2}$ Profil PT. Sunan Drajat Lamongan.

${ }^{3}$ A. Irawan, "Sang Pendidik (Novel Biografi K.H. Abdul Ghofur)", (Jogjakarta: Qalam Nusantara, 2015), h. 45289.
} 
baru yaitu pupuk NPK. Dalam hal peralatan yang menunjang proses produksinya PT Indo Daya Sunan Drajat melakukan kerja sama dengan PT. Putra Perdana Aktual seperti mesin penggiling pupuk dan lain-lain di tahun 1999.

Awal tahun 2004 perusahaan ini berubah nama menjadi PT Sunan Drajat Lamongan karena sudah mendapatkan Akte Notaris dengan status perseroan terbatas yang lingkup usahanya meliputi produksi pupuk dolomit, pospat alam dan NPK di desa Banjarwati, Paciran, Lamongan.

\section{KAJIAN PUSTAKA}

\section{a. Strategi Pemasaran}

Suatu perusahaan sudah pasti mengadopsi aspek pemasaran dalam proses pendistribusian untuk menyediakan dan menyampaikan produk dengan harga dan promosi yang tepat. Bagi Doyle, pemasaran merupakan suatu ilmu yang selalu berkembang menjadi rutinitas perusahaan juga masyarakat di dunia ini. Pemasaran ikut andil besar pada lancarnya suatu distribusi perusahaan karenanya pemasaran merupakan bidang ilmu yang harus diperhatikan bagi para pelaku bisnis.

Hadion W. berpendapat bahwa kegiatan pemasaran adalah suatu kegiatan teratur dan sistematis untuk mengetahui keinginan konsumen dengan diikuti proses perencanaan dan pengembangan produk yang kemudian ditawarkan melalui harga dan promosi.

Strategi pemasaran adalah proses perencanaan yang disusun secara sistematisdan menyeluruh yang digunakan sebagai panduan untuk melakukan kegiatan pemasaran agar mencapai tujuan perusahaan yakni memperoleh laba.

Untuk mencapai tujuan tersebut, setiap perusahaan harus mengelola manajemen perusahaan untuk menuju ketatnya persaingan usaha. Perlu diperhatikan bahwa potensi perusahaan dapat dilihat dari faktor internal dan ekternalnya yaitu sumber dayanya baik aset dan juga manusia, alat produktifitas perusahaan, legalitas perusahaan dan lain sebagainya.dan sebagainya. ${ }^{4}$

Pada dasarnya tujuan dari suatu perusahaan adalah sama yaitu memperoleh keuntungan yang maksimal namun pada produktifitasnya memiliki perbedaan. Oleh karena itu kegiatan pemasaran merupakan komponen penting untuk mencapai tujuan dari perusahaan tersebut. Dengan adanya hal ini perusahaan dapat mengerti akan keinginan konsumen sehingga produktifitas yang dijalankan perusahaan sesuai dengan maksud konsumen juga perusahaan. Strategi yang digunakan oleh beberapa perusahaan akan berbeda sesuai dengan porsi persaingan antar kompetitor dengan memperhatikan kepuasan konsumen melalui produk, harga, tempat pemasaran, dan target sasarannya. Strategi pemasaran disini juga merupakan aspke penting agar tujuan yang hendak dicapai

\footnotetext{
${ }^{4}$ Ika Mary Pasaribu, "Multilevel Marketing Strategy in PT. Oriflame Medan as a Basic Steps for Students of Business Studies", KnE Social Sciences (2008), pages 408.
} 
tidak melenceng serta mengantisipasi beberapa hambatan-hambatan yang dapat memperlambat jalannya perusahaan. ${ }^{5}$

Perusahaan yang mampu bertahan akibat berbagai hambatan seperti krisis ekonomi dikarenakan strategi yang dipakai telah melalui keberhasilan meskipun tidak berjalan normal seperti dahulu kala namun penjualan tetap stabil dan tidak sampai gulung tikar. Banyak jalan yang bisa dilalui oleh para pelaku bisnis untuk tetap bertahan dan bersaing sesuai dengan produk-produk yang dipasarkan. ${ }^{6}$

\section{b. Unit Usaha Pesantren}

Kesadaran bahwa peluang santri dalam membentuk sebuah unit usaha merupakan peluang yang sangat besar. Unit usaha yang berkembang akan membuktikan bahwa lembaga pondok pesantren ini layak untuk didukung. Unit usaha harus memiliki prinsipprinsip sebagai berikut: ${ }^{7}$

a. Unit usaha merupakan milik lembaga, kepala pimpinan tidak mempunyai hak atas kebijakan keuangan.

b. Laporan dan hasil rapat menjadi rutinitas tiap usaha untuk dapat dikembangkan

c. Memanfaatkan SDM yang berasal dari mikro perusahaan agar komunikasi lebih efektif dan efisien.

d. Legalitas perlu diperhatikan guna pengoptimalan peluang.

e. Membuat tim pengawas usaha dengan melibatkan tenaga senior yang mmpuni dalam bidangnya.

\section{c. Bauran Pemasaran (Marketing Mix)}

Bauran pemasaran yaitu kegiatan yang terpadu dan saling menunjang satu sama lain. Keberhasilan perusahaan di bidang pemasaran didukung oleh keberhasilan dalam memilih produk yang tepat, harga yang layak, saluran distribusi yang baik, dan promosi yang efektif.

Empat kebijakan pemasaran meliputi Product (Produk), Price (Harga), Place (Saluran distribusi), dan Promote (Promosi). Menurut Tjiptono bauran pemasaran yang umumnya dipakai oleh perusahaan yaitu: ${ }^{8}$

1. Produk (Product)

Produk merupakan output yang dihasilkan oleh perusahaan yang kemudian ditawarkan kepada konsumen (target sasaran). Bentuk kepuasan dari konsumen pada dasarnya tidak terpaku pada visual produknya saja melainkan bentuk simbolis, psikis,

\footnotetext{
${ }_{6}^{5}$ Kotler \& Armstrong, Prinsip-prinsip Pemasaran, h. 3.

${ }^{6}$ Fitri Yeni dkk, “Analisis Strategi Pemasaran dalam Menghadapi Persaingan Bisnis pada PT. Federal Internasional Finance (FIF) Group di Kecamatan IPUH, Kabupaten Mukomuko. JIMIT, Vol. 1, No. 1, (2019), hal. 42

${ }^{7}$ M. Anggung Manumangso Prasetyo, "Manajemen Unit Usaha Pesantren”, Hikmah, Vol. 6, No. 1 (2017), h. 2627.

${ }^{8}$ Basar Oztaysi et al, (2015), "Target Marketing Strategy Determination for Shopping Malls Using Fuzzy ANP", Vol. 27, pp. 595-623
} 
dan pelayanan yang diberikan oleh perusahaan. Bauran dari produk antara lain kualitas, kemasan, merek, dan layanan.

2. Harga (Price)

Harga merupakan salah satu komponen penting dalam perusahaan untuk memperoleh laba dari konsumen atas barang/jasa yang ditawarkan oleh perusahaan. Penetapan harga merupakan bentuk citra khas dalam masing-masing perusahaan untuk mendapatkan branding dari konsumen. Tingginya harga yang ditetapkan akan membuat konsumen berpandangan bahwa produk yang dikeluarkan adalah berkualitas bagus dan sasaran targetnya adalah kalangan menengah keatas. Dan sebaliknya jika harga yang ditetapkan itu rendah maka produk yang tercipta akan dipandang sebagai produk yang murah dengan kualitas yang rendah. Penetapan harga ini bertujuan untuk pertahanan perusahaan,maksimalisasi laba dari penjualan, dan balik modal. $^{9}$

3. Tempat (Place)

Tempat (distribusi) meliputi aktivitas perusahaan yang membuat produk untuk target konsumen. Penyaluran distribusi membutuhkan kerja sama antar organisasi satu dengan yang lain untuk proses pelancaran barang atau jasa yang siap untuk disalurkan (Kotler, 2005). Lokasi produksi ditunjukkan dengan seluruh aktivitas produsen dalam membuat dan menghasilkan output untuk memenuhi keinginan konsumen dimanapun dan kapanpun konsumen berada. ${ }^{10}$

4. Promosi (Promotion)

Promosi adalah suatu kegiatan yang menyalurkan suatu produk dan menawarkan pelanggan untuk mengonsumsinya. ${ }^{11}$ Promosi merupakan rangkaian aktivitas dari produsen untuk menginformasikan keunggulan dari produknya, merayu, dan menginformasikan para target sasaran supaya membeli produk tersebut dan hal ini merupakan tujuan dari promosi sendiri. (Kotler, 2005). Ada 4 macam promosi yang digunakan oleh setiap perusahaan yaitu:

a) Advertising (Periklanan)

Iklan merupakan sarana digunakan oleh perusahaan sebagai alat komunikasi untuk segala sesuatu produk yang dihasilkan. Diantaranya informasi yang ditawarkan adalah beberapa manfaat serta keunggulan produk. ${ }^{12}$

b) Promosi Penjualan (Sales Promotion)

Promosi penjualan juga digunakan untuk membujuk konsumen agar tertarik pada setiap output yang dihasilkan agar dapat meningkatkan penjualan sekaligus

\footnotetext{
${ }^{9}$ Lipoyadi dan Hamdani, "Manajemen Pemasaran Jasa”, (Jakarta: Salemba), h. 105.

${ }^{10}$ Syauqi Jazuli, “Analisis SWOT Strategi Pemasaran Produk Pembiayaan Produk Pembiayaan pada BMT ElSyifa Ciganjur”, (Skripsi-UIN Syarif Hidayatullah Jakarta, 2016), h. 69.

${ }^{11}$ Dimas H. Wibowo. dkk, "Analisis Strategi Pemasaran untuk Meningkatkan Daya Saing UMKM (Studi pada

Batik Diajeng Solo)”, JAB: Jurnal Administrasi Bisnis, Vol. 29, No. 1 (2015),h. 60.

${ }^{12}$ Kasmir, Pemasaran Bank, (Jakarta: Prenda Media, 2005), h. 177.
} 
menarik konsumen baru. Promosi penjualan ini biasanya melalui sale, undian berhadiah, atau contoh produk.

c) Publisitas (Publicity)

Suatu bentuk penyajian dan penyebaran ide, barang secara non personal yang diuntungkan tidak mendapat biaya untuk hal tersebut melainkan pemanfaatan nilai-nilai berita yang terkandung dalam suatu produk untuk membentuk citra produk yang bersangkutan.

d) Penjualan Pribadi (Personal Selling)

Penjualan pribadi (personal selling) berarti transaksi mouth to muth (dari mulut ke mulut) antara pembeli dan penjual. Skill ini sangat dibutuhkan karena sangat berpengaruh terhadap keinginan konsumen pada produk yang ditawarkan.

\section{d. Analisis SWOT}

Analisis SWOT adalah metode strategis untuk sebuah perencanaan yang bertujuan untuk mengevaluasi Strenght (Kekuatan), Weakness (Kelemahan), Opportunities (Kesempatan), dan Threats (Ancaman) dalam suatu proyek atau bisnis usaha. ${ }^{13}$ SWOT ini biasanya berguna untuk menganalisa suatu kondisi dimana akan dibuat sebuah perencanaan untuk melakukan suatu program kerja. (Buchari Alma, 2008). Potensi yang dimiliki oleh perusahaan akan di observasi melalui kondisi suatu perusahaan baik dari faktor internal maupun eksternalnya serta mengenai ancaman yang dihadapi perusahaan akan ditemukan jika menggunakan analisa ini. Menentukan tujuan dari suatu usaha bisnis dengan mengidentifikasi faktor-faktor yang akan mengakibatkan keuntungan maupun kerugian suatu perusahaan juga akan terlibat dalam analisis SWOT ini.

\section{METODE PENELITIAN}

Teknik pengumpulan data yakni melalui literasi beberapa pustaka yaitu buku, laporan penelitian, sumber terpercaya, jurnal dan bahkan skripsi yang mungkin menjadi pendukung dalam penulisan suatu karya tulis ilmiah ini. Beberapa sumber pokok yang telah digunakan yakni buku, website dan jurnal internasional maupun nasional sumber resmi dari PT. Sunan Drajat Lamongan.

\section{HASIL DAN PEMBAHASAN}

Pada tahun 2004, PT. Sunan Drajat Lamongan merupakan perusahaan swasta nasional yang bergerak di bidang pemuatan pupuk dengan lokasi pabrik "Kawasan Industri Pondok Pesantren Sunan Drajat (KISDA)" di desa Banjarwati, Paciran, Lamongan. Perusahaan 2 hektar ini terdiri dari bangunan kantor, gudang, tempat produksi, gudang produk dan laboratorium uji, dimana secara keseluruhan terus dilakukan pengembangan pembangunannya. PT SDL (Sunan Drajat Lamongan) ini merupakan salah satu unit wirausaha Pondok Pesantren

\footnotetext{
${ }^{13}$ Freddy Rangkuti, Analisis SWOT Teknik Membedah Kasus Bisnis, (Jakarta: PT. Gramedia Pustaka Utama, 2006), h. 19.
} 
Sunan Drajat untuk menopang perekonomian pondok. ${ }^{14}$ PT. Sunan Drajat Lamongan merupakan perusahaan tambang phosfat yang beroperasi secara tersturktur dan terintegrasi, diantaranya mulai dari aktivitas menambangan, mengolah, rehabilitasi lahan, sampai memasarkan.

K. H Abdul Ghofur sebagai pendiri Pondok Pesantren Sunan Drajat sekaligus menjadi penemu ide entrepreneur. Hal ini didasarkan pada filosofi tujuh sap tangga Sunan Drajat yang memotivasi beliau untuk membangun salah satu santripreneur ini. Maksud dari pesan tersebut yaitu “agar orang yang lemah, terdzolimi dan marginal perlu di tolong”. Maka dari itu, dapat menciptakan lembaga yang lebih berkualitas, dan lebih berkembang pada era revolusi industri 4.0 ini dengan meningkatkan kemandirian pesantren melalui program santripreneur/entrepreneurship.

Strategi pemasaran pada PT. Sunan Drajat Lamongan sampai saat ini dalam proses peningkatan dan juga pengembangan diantaranya memanfaatkan sumber daya perusahaan, menciptakan industri yang kreatif dan inovatif, mengoptimalkan nilai-nilai integrasi dalam mencapai target sesuai dengan visi dan misi.

Bauran pemasaran dikenalkan kali pertama oleh N. H. Borden pada tahun 1964 dan kemudian dikembangkan oleh Jerome Mc Carthy agar proses pengelolaan pada perusahaan dapat menguntungkan. Berdasarkan hasil riset dari beberapa literature maka dapat di konklusikan bahwa yang dilakukan oleh PT. SDL (Sunan Drajat Lamongan) dalam strategi pemasarannya dapat diketahui hasil pembauran pemasarannya yakni:

\section{a. Product (Produk)}

Produk yang di pakai PT. SDL (Sunan Drajat Lamongan) adalah pupuk organik dengan berkualitas tinggi, murah, dan ramah lingkungan. Pupuk yang diproduksi terdiri dari Pupuk Dolomite sesuai SNI 02-2804-1992, Pupuk Phosphate untuk pertanian sesuai SNI 02-3776-1995, dan Pupuk NPK Padat sesuai SNI 02-2803-2000. Kapasitas produksi perbulan sekitar 2000-5000 ton, 10.000-20.000 ton untuk Dolomite, 10.000 ton Phosphate. Alasan pendiri perusahaan ini memproduksi pupuk karena melihat sumber daya alam khususnya sumber mineral pada wilayah tersebut kurang diberdayakan secara maksimun. Padahal potensi yang dihasilkan cukup besar apabila sumber daya tersebut dimanfaatkan secara baik. Setelah dilakukan uji coba, ternyata batu kapur tersebut mengandung dolomit dan juga pospat yang bisa diproduksin menjadi pupuk. Meskipun menggunakan teknologi sederhana namun hal tersebut tidak mengabaikan kualitas produk yang dihasilkan.

Pada dasarnya suatu produk memiliki beberapa fase diantaranya fase pertumbuhan, kematangandan penurunan penjualan. Perusahaan harus meng-cross check output mereka hasilkan untuk memperoleh permintaan yang lebih banyak setelah mengalami beberapa

\footnotetext{
${ }^{14}$ B. Ahwarumi, "Perencanaan Strategis Sistem Informasi Pondok Pesantren Sunan Drajat dalam Rangka Pengendalian Internal Organisasi”, (Skripsi-UIN Malang, 2011), h. 117.
} 
fase tersebut dengan menciptakan strategi diversifikasi dan menigkatkan kedalam lini produk tersebut. $^{15}$

b. Price (Harga)

Harga merupakan salah satu komponen penting dalam perusahaan untuk memperoleh laba dari konsumen atas barang/jasa yang ditawarkan oleh perusahaan. Penetapan harga merupakan bentuk citra khas dalam masing-masing perusahaan untuk mendapatkan branding dari konsumen.

PT. Sunan Drajat Lamongan mengkisar untuk satu truk batu kapur di jual Rp. 15.000, tetapi jika untuk kosmetik, bisa laku Rp. 15.000.000. Hal ini dikarenakan bubuk dolomite berguna untuk campuran baja dan juga kosmetik. Visi dan misi yang dijunjung yaitu dengan menjadi pelopor dalam industri pupuk organik dengan menyediakan pupuk organik yang berkualitas tinggi, murah ramah lingkungan dan menjaga kelestarian alam.

Harga merupakan salah satu bentuk yang membuat persepsi produk dimata konsumen. Penetapan tinggi rendahnya harga akan selalu menjadi pembanding dalam membeli produk dimata pelanggan.

c. Place (Tempat)

Selain pada kedua hal tersebut diatas, bahwa saluran distribusi menjadi bagian terpenting juga. Lokasi yang strategis sangat diperlukan dalam proses pendistribusian produk agar mudah diakses oleh pembeli. ${ }^{16}$

PT. Sunan Drajat Lamongan ini terletak di desa Banjarwati,Lamongan yang letaknya \pm 39 kilometer yang secara geografisnya dari arah selatan kota Lamongan dan sebelah utara berbatasan dengan Laut Jawa dan merupakan lintasan jalur utara Surabaya-Tuban dan desa Banjarwati termasuk dalam kategori desa dengan tingkat ekonomi dan kondisi masyarakat yang bervariatif.

Mayoritas penduduk desa Banjarwati ini adalah nelayan, namun terdapat juga profesi seperti petani, pedagang, pegawai negeri atau swata dan lain sebagainya. Melihat letak geografisnya desa ini menjadi lokasi yang strategis untuk membangun industri. Selain itu, melihat pangsa pasarnya, PT. Sunan Drajat Lamongan kemudian memperluas produksi tambangnya di desa Banjaranyar yang luasnya kurang lebih menjadi 60 hektar dari 2 hektar di tahun 2004.

d. Promotion (Promosi)

Selain ketiga hal diatas, promosi juga merupakan aspek penting dalam pemasaran yang berperan besar untuk meningkatkan brand dan penjualan. Promosi dipandang sebagai arus informasi atau persuasi satu arah yang dibuat untuk mengarahkan seseorang atau organisasi agar melakukan pertukaran dalam pemasaran. ${ }^{17}$

\footnotetext{
${ }^{15}$ Tengku F. Musfar, "Bauran Pemasaran sebagai Materi Pokok dalam Manajemen Pemasaran“ (Bandung: CV Media Sains Indonesia, 2020), hal. 12

${ }^{16}$ M. Fuad dkk, "Pengantar Bisnis" (Jakarta: PT Gramedia Pustaka Utama, 2006), hal 129-130.

${ }^{17}$ Tengku F. Musfar, Buku Ajar Manajemen Pemasaran Bauran Pemasaran sebagai Materi Pokok dalam Manajemen Pemasaran (Bandung: CV. Media Sains Indonesia, 2020), hal. 13-14.
} 
Promosi yang dipakai PT. Sunan Drajat Lamongan adalah dengan memakai internet marketing yaitu melalui website dan social media, menjalin kerjasama ke perusahaan maupun instansi, turut aktif menjadi sponsor kegiatan, mouth to mouth, pekerja kapur maupun kosmetik. Hal ini sebenarnya sudah sangat efektif karena dengan adanya promosi ini banyak konsumen yang mengetahui kualitas produk pupuk ini, tetapi sudah banyak juga usaha serupa yang muncul dengan promosi yang besar-besaran. Meskipun begitu pangsa pasar dari produksi di PT. Sunan Drajat Lamongan sudah menjangkau ke ranah domestik yaitu di Sumatera, Jawa Tengah, Nusa Tenggara Barat dan lainnya. Sedangkan dalam pasar luar negeri yaitu Jepang dan Australia, terkhusus pada produk pupuk Pospat untuk pertanian.

PT. Sunan Drajat Lamongan sudah berdiri sejak 2004 dengan merek produk kemasan Kawasan Industri Sunan Drajat (KISDA) dan tetap eksis sampai saat ini dan mendapat julukan pondok pesantren entrepreneur dari pemerintah karena mempunyai unit usaha yang begitu banyak di berbagai bidang. Berikut adalah rincian mengenai analisa SWOT menurut perspektif penulis didukung oleh data yang sudah dijabarkan diatas:

a. Strenght (Kekuatan)

1) Memiliki mutu dan produk sudah terjamin disertai dengan label SNI

2) Kefektifan proses penyaluran distribusi.

3) Memiliki citra produk yang baik karena dinaungi oleh Pondok Wirausaha

4) Memiliki produk unggulan yang sudah terjamin kualitasnya

5) Karyawannya terdiri dari masyarakat sekitar Lamongan, yang berarti sudah membuat lapangan pekerjaan agar menumpas pengangguran pada daerah Lamongan

6) Susunan manajemen kerja terstruktur secara efektif dan efisiensi

b. Weakness (Kelemahan)

1) Kurangnya strategi promosi yang kurang meskipun sudah familiar di kancah domestic maupun internasional namun harus tetap mengembangkannya untuk bersaing dengan kompetitor lain.

2) Kurangnya mengembangkan perusahaan diberbagai kota maupun daerah guna meluasnya jaringan perusahaan.

c. Opportunity (Peluang)

1) Mempunyai target pasar dan konsumen yang jelas, yang membuat perusahaan dapat mengidentifikasi keuntungan dari pendapatan.

2) SDM yang sudah mencukupi

3) Menjadi bahan produk yang eksis di masa sekarang

4) Membuka lapangan pekerjaan

d. Threat (Ancaman)

1) Unggulnya promosi dari pesaing

2) Banyaknya kompetitor baru yang lebih meminimkan harga 
Dari analisis SWOT yang sudah terjabarkan diatas, maka penulis dapat menyimpulkan bahwa sudah mencukupi ranah kemajuan dalam suatu Pondok Pesantren yang membuka bisnis bidang industri ini, meskipun terdapat beberapa kekurangan. Meskipun begitu Pondok Pesantren SunanDrajat ini telah diakui sebagai Pesantren Wirausaha, yang terbukti dengan berbagai bidang usaha yang telah didirikan. Hal ini membuktikan bahwa Pondok Pesantren Sunan Drajat telah meningkatkan eksistensi pondok pesantren di era revolusi 4.0 saat ini, salah satu perusahan terbesarnya adalah PT. Sunan Drajat Lamongan. Meskipun persaingan ketat terjadi antara PT. Sunan Drajat Lamongan dengan PT. Polowijo Gresik karena memiliki persamaan dari aspek produk, pangsa pasar, serta lokasi yang cukup dekat. Namun PT Sunan Drajat Lamongan mampu mempertahankan semua aspek dan distribusi berjalan cukup efektif dan efisien.

\section{KESIMPULAN}

Dapat disimpulkan berdasarkan hasil analisis data, literasi serta teori yang relevan bahwa PT. Sunan Drajat Lamongan dalam kegiatan pemasarannya dengan memanfaatkan kekayaan sumber daya alam (SDA) didaerah sekitarnya dan mengelolanya dengan berbagai jenis produknya. Pada tempat (distribusi) PT. Sunan Drajat Lamongan cukup strategis karena terletak di daerah perbatasan. Penetapan harga ditentukan sesuai dengan harga pasaran dan juga telah disahkan produk telah ber-SNI yang terbukti akan kualitas sehingga mempengaruhi minat pembeli. Pendistribusiannya juga sudah dilakukan ke berbagai kota di Inonesia serta melakukan ekspansi ke luar negeri. Dalam mepromosikan produknya PT. Sunan Drajat Lamongan memakai internet marketing (melalui website dan sosial media), menyebarkan email ke perusahaan maupun instansi, menjadi sponsor kegiatan, dan mouth to mouth.

\section{DAFTAR PUSTAKA}

A. Nasution, Fadli, et.al. "Building Customer Loyalty Through Marketing Mix Strategy with Satisfactory as Intervening Variable" in The 2018 International Conference of Organizational Innovation, KnE Social Sciences.

Adiyanto, Yoga. "Analisis Strategi Pemasaran Makanan Tradisional Ranginan (Rengginang) di Kabupaten Pandeglang”, Jurnal Bina Bangsa Ekonomika. Vol. 13, No. 2, 2020.

Erfan A, Moh. "The Political Marketing Strategy of Mayor and Deputy Mayor of Malang City (A Phenomenological Study on the Success of Mohammad Anton and Sutiaji (Mas) in Winning the Mayor Office)", KnE Social Sciences, 2018.

B, Wardi. Metodologi Penelitian Ilmu Dakwah. Jakarta: Logos, 1987.

Chen, Quan et al. "an Empirical Research on Marketing Strategies of Different Risk Preference Merchant:” MPE. Volume 2018. 
Dwija Utama, Iston. “Analisis Strategi Pemasaran pada Usaha Mikro Kecil dan Menengah (UMKM) pada Era Digital di Kota Bandung”, EQUILIBRIUM, Vol. 7, No. 1, 2019.

F. Musfar, Tengku. Bauran Pemasaran sebagai Materi Pokok dalam Manajemen Pemasaran. Bandung: CV. Media Sains Indonesia, 2020.

Fuad ,M dkk. Pengantar Bisnis. Jakarta: PT Gramedia Pustaka Utama, 2006

Habiburrohman. "Edupreneurship di Pondok Pesantren (Pondok Pesantren Sunan Drajat: Pesantren Wirausaha)”. Tesis_-UIN Sunan Kalijaga, Jogjakarta, 2018.

Irawan, A. Sang Pendidik. Jogjakarta: Qalam Nusantara, 2015.

Kasmir. Pemasaran Bank. Jakarta: Prenda Media, 2005.

K, Feibe, dkk. "Analisis Strategi Pemasaran dalam Meningkatkan Penjualan Motor Yamaha Mio pada PT. Hasjrat Abadi Outlet Yamaha Sam Ratulangi”, EMBA. Vol. 6, No. 2, 2018.

Kulsum, Umu, dkk. "Manajemen Strategik dalam Pengelolaan Pesantren”, Tadhir. Vol. 3, No. $1,2018$.

Manumangso Prasetyo, M. Anggung . "Manajemen Unit Usaha Pesantren”. Hikmah, Vol. 6, No. 1, 2017.

Mufa'izah dan Ritonga, Iskandar. "Strategi Pondok Pesantren Sunan Drajat dalam Mengimplementasikan Branding sebagai Pondok Kewirausahaan dan Implikasinya terhadap Jiwa Kewirausahaan Santri”, El Qist, Vol.07, No.02, 2017.

Profil PT. Sunan Drajat Lamongan.

Popescu, Mirona A.M and Miroslav, Silviu V. "Implementing an Online Marketing Strategy for an IT Company". Vol. 27, 2017.

Rifani Permatasari, Ita. "Analysis of Entrepreneurship Characteristik, Venture Capital, and Marketing Strategy on Succes of Small Industry Enterprise", JAM : Jurnal of Applied Management. Vol. 15, No. 3, 2017.

Viendyasari, Mila. “Application of 'KISS' Priciple on Marketing Mix Strategy (Firmax3 Product Through Network Marketing in Indonesia): Case Study”. KnE Social Sciences. 